Ethiopian Journal of Environmental Studies \& Management 8(4): 464 - 470, 2015.

ISSN:1998-0507

doi: http://dx.doi.org/10.4314/ejesm.v8i4.11

Submitted: March 12, 2015 Accepted: May 07, 2015

\title{
EARTHWORM CAST BIOMASS UNDER THREE MANAGED ECOSYSTEMS: IMPLICATION FOR SOIL FERTILITY
}

*DEDEKE, G.A., BABATUNDE, 0. AND ALADESIDA, A.A.

Department of Biological Sciences, Federal University of Agriculture, Abeokuta, Nigeria

\begin{abstract}
The study was conducted to determine earthworm cast biomass under three managed ecosystems, Gmelina, Cashew and Banana plantations at Federal University of Agriculture, Abeokuta and its impact on the soil physicochemical parameters. Seven, five and four plots of $3 \mathrm{~m}^{2}$ each were sampled in Gmelina, Cashew and Banana plantations respectively. Each plot was laid out in form of a grid and seven quadrats of $44 \mathrm{~cm} \times 44 \mathrm{~cm}$ each were sampled in each plot. On-field Cast weights were determined to the nearest gram using a top loading mechanical balance and the cast biomass was calculated from these. The nutrient and mineral properties of both earthworm casts and parent soils were determined using standard methods of AOAC. The \% OC (4.61), \%OM (7.96), sulphate (38.37), pH (7.78), total nitrogen (0.27), $\mathrm{Mn}$ (0.47) and Fe (7.23) were significantly higher $(p<0.05)$ in the earthworm casts under Gmelina plantation compared with the cashew and banana plantations. $\mathrm{Cu}$ and Fe concentrations in the parent soil under Gmelina plantation were significantly higher $(p<0.05)$ than under cashew and banana plantations while $\mathrm{Mg}$ and $\mathrm{Mn}$ concentrations showed no significant difference. Compared with the parent soil, \%OC, \%OM, Mn and Fe obtained from earthworm casts were significantly higher $(p<0.05)$ under all three plantations. Earthworm cast biomass under the Gmelina plantation $\left(15483.63 \mathrm{~g} / \mathrm{m}^{2}\right)$ was significantly $(p<0.05)$ higher than that obtained under the cashew $\left(13270.83 \mathrm{~g} / \mathrm{m}^{2}\right)$ and banana (8828.13) plantations. The present results showed that earthworm activity is better supported under Gmelina than cashew and banana plantations In addition, the higher cast biomass and nutrient level in the parent soil under Gmelina plantation signifies a significantly higher nutrient level which, expectedly means that the Gmelina plantation soil will be more fertile than the soil in cashew and banana plantations.
\end{abstract}

Key Words: Earthworm cast, Gmelina, Cashew, Banana, physicochemical

\section{Introduction}

Earthworms are long time adored creatures in many cultures, probably because of the role they are believed to play in the fertility improvement of soil. The Chinese characterized earthworms as the "angel of the earth". Aristotle aptly referred to them as the intestines of the soil though he might be referring to the appearance rather than their functions (Ramsay and Hill, 1978; Blakemore, 2003).

Earthworms significantly affect plant growth through their effects on microorganisms, aggregation of soil, and

*Corresponding Author: Dedeke, G.A.

Email: gabrieldedekson@gmail.com 
nutrient supply (Sabrina et al., 2009). surface, consuming soil along the way. Coiled soil masses known as casts are excreted from the worm's digestive system, making the soil more fertile. The earthworm's burrowing action continually moves mineral-rich soil to the surface, which improves plant growth.

Earthworms contribute to soil turnover, structure and formation and serve as a fertility enhancer in various ways. Earthworms and their casts are useful in land improvement, reclamation and in organic waste management (Edwards and Baker, 1992; Lavelle and Martin, 1992; Johnson, 1997; Villenave et al., 1999). Soil productivity can be improved by manipulating the community of earthworms in the soil (Brown et al., 1999).

Earthworms have important roles in soil physical, chemical and biological properties (Edwards, 2004). Earthworms eat soil organic matter and litter and increase availability of plant nutrients in their casts (Brown et al., 2004). The nutrients can increase plant growth and yield of crops as a result (Edwards and Bohlen, 1996). These are good indicators that the earthworm activities and behaviour interact strongly with physical, chemical and biological properties of the soil (Pattana and Pongthep, 2009).

Casting by earthworm is an important activity which has been shown by several studies to have significant impact on soil fertility. A worm casting is a biologically active mound containing several bacterial, enzymes and remnants of plant materials and animal manure that were not digested by the earthworm (Appelhof, 1982). Earthworm casts contain 5 times more nitrogen, 1.5 times more calcium, 3 times more magnesium, 11 times more potash and 1.4 times more humus than the original top soil (Edwards and Lofty, 1997). Elliot
Earthworm burrows deep below the soil et al., (1990) noted that earthworm casts generally have a higher ammonium concentration and water holding capacity than the corresponding original top soil. Fresh casts are easily dissolved by water noticeably during rainfall events. Worm casts around the bases of plants act as heat radiators, thereby causing a lowering of temperature at the surface casting (Owa $e t$ al., 2004).

In spite of the many benefits that accrued to soil by the activity of earthworm, information on earthworm cast biomass with relation to their impact on soil fertility under different plantations has not been fully studied. The broad objective of this study therefore, is to establish the relative contribution of earthworm cast biomass to soil fertility, under three plantations; Gmelina, Cashew and Banana, on the Federal University of Agriculture campus in Abeokuta.The specific objectives are to:

1. Estimate earthworm cast biomass under Gmelina, Cashew and Banana Plantations in the dry season.

2. Estimate the amount of nutrient held in earthworm cast biomass under Gmelina, Cashew and Banana Plantations in the dry season.

3. Determine the relationship of plantation types to earthworm cast biomass and nutrient in relation to tree canopies and leaf litter

\section{Materials and Methods}

The study was conducted during the dry season between December 2010 and February 2011 at the Federal University of Agriculture, Abeokuta, Ogun State, Nigeria $7.23^{\circ} \mathrm{N}$ and $3.44^{\circ} \mathrm{E}$. During this period earthworms have gone into aestivation due 
to the high ambient temperature and very low humidity.

Earthworm cast and soil samples were collected under three different managed plantations within the University viz the University Arboretum which, is the nursery for growing Gmelina arborea, also known as Gmelina; the Cashew plantation located at about 300 metres to the Arboretum and the Banana plantation in the Fadama farm of the university located at about 300 metres from and cashew plantation and 300 metres from the Arboretum.

Depending on the size of the plantation, seven, five and four plots of $3 \mathrm{~m}^{2}$ each were sampled in Gmelina, Cashew and Banana plantations respectively. Each plot was marked out in form of a grid and seven quadrats of $44 \mathrm{~cm} \mathrm{x} 44 \mathrm{~cm}$ each were sampled in each plot. Earthworm casts and soil samples were collected from alternative quadrats manually by hand picking into separate polythene bags and labelled. The cast and soil sample collected per quadrat were weighed using a top loading mechanical balance. The weighed casts were returned back into their respective quadrats and only small quantities were transferred to the soil laboratory for analysis.

At the soil laboratory of the University, the earthworm casts and soil samples were air-dried till constant weight was reached. The earthworm cast and soil were ground by mechanical means to fine particle sizes and sieved through a 2-mm mesh sized sieve to obtain a fine particle sized casts and soil. The samples were analysed for $\%$ Organic matter (OM), \% Organic carbon (OC), pH, total nitrogen, sulphate concentration, nitrate concentration and mineral elements.

The means of the soil and earthworm parameters measured were compared using analysis of variance and independent T-test as necessary. The earthworm cast properties were also related to the soil properties and vegetation type. The statistical analysis was carried out using the Statistical Package for Social Sciences (SPSS) version 17.

\section{Results}

The \%OC (4.61), \%OM (7.96), sulphate (38.37), $\mathrm{pH}$ (7.78) and total nitrogen (0.27) were significantly higher $(\mathrm{p}<0.05)$ in the earthworm casts under Gmelina plantation compared with the cashew and banana plantations, while there was no significant difference $(p>0.05)$ in the percentage nitrate obtained from the earthworm casts under all the plantations (Table 1). In the parent soil, the \% OC (2.15), \% OM (3.94), nitrate (0.61) and total nitrogen (0.44) under Gmelina plantation were significantly higher $(\mathrm{p}<0.05)$ than under the cashew and banana plantations while the $\mathrm{pH}$ and percentage sulphate obtained under all the plantations were not significantly different $(\mathrm{p}>0.05)$ (Table 1).

The result of the mineral analysis of soil and cast showed no consistent pattern between the different plots. While copper content was highest in earthworm casts from the banana plot, in the soil, it was highest in the Gmelina collection (Table 2); there was no significant difference between the copper content in Gmelina and banana in the cast but was significantly higher in soil from the Gmelina plot than the other 2 plots $(\mathrm{P}<0.05)$.

It was observed that the $\mathrm{Cu}$ concentration obtained from the earthworm cast under banana (0.09) and Gmelina (0.07) plantations were similar in value but significantly higher $(\mathrm{p}<0.05)$ than the value obtained under cashew plantation (0.01). In addition, the concentrations of $\mathrm{Mg}$ and $\mathrm{Na}$ obtained from the earthworm cast under all plantations were not significantly different (p>0.05) (Table 2). 
The concentration of Mn obtained from the earthworm cast under all plantations were significantly different $(\mathrm{p}<0.05)$ with the concentration obtained under Gmelina (0.47) recording a higher value than those obtained under cashew (0.44) and banana (0.31) plantations. The $\mathrm{Fe}$ concentration also showed a similar trend to that of $\mathrm{Mn}$ with the concentration obtained from the cast under Gmelina (7.23) being significantly higher than that under cashew (6.03) and banana (5.47) plantations (Table 2).

A similar trend to that of $\mathrm{Cu}$ was observed for $\mathrm{K}$ with the $\mathrm{K}$ concentration obtained from earthworm cast under banana (1.42) and Gmelina (1.23) being the same were significantly higher $(\mathrm{p}<0.05)$ than the value obtained under cahew (1.09) (Table 2).

The results obtained from the parent soil showed that the $\mathrm{Cu}$ and $\mathrm{Fe}$ concentrations were significantly higher $(\mathrm{p}<0.05)$ under Gmelina than under cashew and banana plantations. There were no significant differences in the $\mathrm{Mg}$ and $\mathrm{Mn}$ concentrations obtained from the parent soil under all the three plantations (Table 2).

The Na concentration obtained from the parent soil under the banana (1.46) and that under the Gmelina (1.41) were similar but significantly higher $(\mathrm{p}<0.05)$ than that obtained under the cashew (1.08). Similarly, K concentration obtained under the banana (0.95) and that under Gmelina (0.73) were the same but both were significantly higher $(\mathrm{p}<0.05)$ than that obtained under the cashew (0.59) (Table 2).

The comparison of values obtained from the earthworm casts with that from parent soil revealed that the \%OC, \%OM, $\mathrm{Mn}$ and Fe obtained from earthworm casts were significantly higher $(\mathrm{p}<0.05)$ than that obtained from the parent soils under all three plantations. Also the value obtained for sulphate from the cast was significantly higher $(p<0.05)$ than that obtained from the parent soil under Gmelina plantation (Table $3)$. On the other hand, there were no significant difference $(p>0.05)$ in the concentrations of nitrate and $\mathrm{Cu}$ obtained from earthworm casts and parent soils under all the plantations (Table 3 ).

There was no significant difference between the $\mathrm{Mg}$ concentrations obtained from the earthworm cast compared to the parent soil under all plantations except the cashew. Although the $\mathrm{Na}$ concentration from earthworm cast were higher than the parent soil under all plantation only that obtained under cashew was significant $(\mathrm{p}<0.05)$ (Table 3).

It was also observed that the $\mathrm{K}$ concentration obtained from earthworm cast under Gmelina and cashew plantations were significantly higher $(\mathrm{p}<0.05)$ than the parent soil whereas that obtained from the cast under banana plantation was higher than the parent soil, it was not significant (p>0.05) (Table 3).

\section{Discussion}

The present results agree with the study of Elliot et al. (1990) and Edwards and Lofty (1997) which, showed that earthworm casts contain 5 times more nitrogen, 1.5 times more calcium, 3 times more magnesium, 11 times more potash and 1.4 times more humus, higher ammonium concentration and water holding capacity than the corresponding original top soil.

It was observed that the weight of earthworm cast and the calculated earthworm cast biomass under the Gmelina plantation $\left(15483.63 \mathrm{~g} / \mathrm{m}^{2}\right)$ was significantly $(\mathrm{p}<0.05)$ higher than that obtained under the cashew $\left(13270.83 \mathrm{~g} / \mathrm{m}^{2}\right)$ and banana $\left(8828.13 \mathrm{~g} / \mathrm{m}^{2}\right)$ plantations. Using the above as indices of earthworm activities, the trend revealed a higher incidence of 
earthworm activities in the immediate past rainy season under the Gmelina plantation compared to the other plantations.

Several probable synergistic reasons could have resulted in the above observations; high litter level, high organic matter level, denser canopy structure, palatability of leaf litter and low disturbance/human activities at the base of the plantations. A higher litter level, denser canopy structure and low disturbance of the forest floor was observed for Gmelina plantation which, resulted in the higher organic matter, organic carbon and higher mineral elements. Logson (1994) showed that higher litter level enhances increased population of earthworms because this will provide not just shelter but food to the earthworm which will invariably enhance cast production activities. Schmidt et al. (2003) also emphasized that land use is a factor that influences the diversity and population of earthworm.

Sabina et al. (2009) reported that population of $P$. corethrums in tropical tree plantations in Huwai are influenced strongly by tree species, particularly the palatability of leaves to earthworm. Earthworm ingest selected soil particles, soil organic matter, dead plant material, seed or seedlings and micro-organism, this may affect the chemical and physical properties of casts as compared to the surrounding soils.

Deriving from the above therefore are the following major observations (1) earthworm casts contains higher amount of nutrients compared to the parent soils under all the three plantations (2) Gmelina plantation contains significantly higher earthworm cast biomass (3) parent soil under Gmelina plantation contain a higher amount of nutrient than under the cashew and banana plantations.

The import of these therefore, is that there is potentially large amount of nutrients locked up in the earthworm casts which, will be released into the soil at the advent of the rainy season and thereby increasing the soil fertility and enhancing plant growth and development in the plantations. In addition, the higher cast biomass and nutrient level in the parent soil under Gmelina plantation signifies a significantly higher nutrient level which, expectedly means that the Gmelina plantation soil will be more fertile than the soil in cashew and banana plantations.

\section{Acknowledgement}

We wish to acknowledge the contributions of $\mathrm{Mr}$ Olopade, the Chief Technologist at the Department of Environment Management and Toxicology Laboratory, Federal University of Agriculture, Abeokuta for his efforts in helping with the analysis of the earthworm cast and soil samples.

\section{References}

Appelhof, M. (1982). Worms eat my Garbage. Flower Press, Kalamazoo, Michigan. Retrieved on $15^{\text {th }}$ November 2012 from http://aggiehorticulture.tamu.edu/plantanswers.pu blications/worms/worms.html

Blakemore, R. (2003). Fact sheets on earthworms casting. Queen Victoria Museum, Launceston.

Brown, G.G., Pashanasi, B, GilotVillenave, C., Patrón J.C., Senapati, B.K., Giri, S., Barois, I., Lavelle, P., Blanchart, E., Blakemore, R.J., Spain, A.V. and Boyer, J. (1999). Effects of earthworms on plant production. In: Lavelle, P., Brussaard, L. and Hendrix, P. F. (Eds). Earthworm Management othamin Tropical Agroecosystems. CAB International, Wallingford, United Kingdom, 87147pp. 
Brown, G.G., Benito, N.P., Pasini, A., Sautter, K.D., Guimaraes, M. and Torres, E. (2004). No-tillage greatly increases earthworm populations in Parana State, Brazil. Pedobiologia, 47: 764-771.

Edwards, C.A. (2004). Earthworm ecology. $2^{\text {nd }}$ edition. Florida: CRC Press.

Edwards, C.A. and Baker, J.E. (1992). The use of earthworms in environmental management. Soil Biology Biochemistry, 24: 1683-1689.

Edwards, C.A., and Bohlen, P.J. (1996). Biology and Ecology of earthworms. $3^{\text {rd }}$ edition., London: Chapman and Hall.

Edwards, C.A. and Lofty, J.R. (1997). The invertebrate fauna of the Park Grass plots: In Soil fauna. Rothamsted Report, 2:133-154.

Elliot, P.W., Knight. D. and Anderson, J. M. (1990). Denitrification in earthworm casts and soil from pastures under different fertilizer and drainage regimes. Soil Biology Biochemistry, 22(5): 601-605.

Johnson, D. L. (1997). Earthworms casts reflect soil conditions. Agriculture Research, 45:19.

Lavelle, P. and Martin, A. (1992). Smallscale and large-scale effects of endogeic earthworms on soil organic matter dynamics in soils of the humid tropics. Soil Biology Biochemistry, 24:1491-1498
Logson, G. (1994). Worldwide progress in vermicomposting. BioCycle, 35(10):62-65

Owa, S.O. Moreyibi, H.O., Dedeke, G.A., Olojo, F.O. and Fashunwon, O.O. (2004). Earthworm-created micoenvironment around roots of lowland rice. Journal of Science. Engineering and Technology, 11(1): 5261-5270.

Ramsay, J.A. and Hill, S.B. (1978). Earthworms the agriculturist's friends. Macdonald Journal, 39 (10): 6-8.

Sabrina, D.T., Hanafi, M.M., Nor Azwady, A.A. and Mahmud, T.M.M. (2009). Earthworm populations and cast properties in the soils of oil palm plantations. Malaysian Journal of Soil Science, 13: 29-42.

Schmidt, O., Clements, R.O. and Donaldson, G. (2003). Why do cereal-legume intercrops support large earthworm populations. Applied Soil Ecology, 22(2): 181-190.

Villenave, C., Charpentier, F., Lavelle, P., Feller, C., Brussard, L., Pashanas, B., Barois, I., Albrecht, A., and Patron, J. C. (1999). Effects of earthworms on soil organic matter and nutrient dynamics following earthworm inoculation in field experiment situations. In: Lavelle, P., Brussarrd, L., and Hendrix, P. (Eds.). Earthworms Management in Tropical Agroecosystems. CAB International Publishing.173-198pp.

Table 1: Descriptive statistics of physicochemical parameters in the earthworm casts

\begin{tabular}{lrrr}
\hline & Gmelina $(\mathrm{n}=7)$ & Cashew $(\mathrm{n}=5)$ & Banana $(\mathrm{n}=7)$ \\
\cline { 2 - 4 } Parameters & Mean \pm SD & Mean \pm SD & Mean \pm SD \\
\hline$\%$ OC & $4.61 \pm 0.50^{\mathrm{b}}$ & $3.19 \pm 0.48^{\mathrm{a}}$ & $3.30 \pm 0.75^{\mathrm{a}}$ \\
$\%$ OM & $7.96 \pm 0.86^{\mathrm{b}}$ & $5.51 \pm 0.83^{\mathrm{a}}$ & $5.71 \pm 1.29^{\mathrm{a}}$ \\
Nitrates & $0.66 \pm 0.15^{\mathrm{a}}$ & $0.52 \pm 0.15^{\mathrm{a}}$ & $0.50 \pm 0.07^{\mathrm{a}}$ \\
Sulphates & $38.37 \pm 17 .^{\mathrm{b}}$ & $1.90 \pm 0.14^{\mathrm{a}}$ & $8.08 \pm 0.16^{\mathrm{a}}$ \\
pH & $7.78 \pm 0.19^{\mathrm{b}}$ & $7.42 \pm 0.17^{\mathrm{a}}$ & $7.72 \pm 0.33^{\mathrm{a}} \mathrm{b}$ \\
Total Nitrogen & $0.27 \pm 0.05^{\mathrm{b}}$ & $0.15 \pm 0.07^{\mathrm{a}}$ & $0.22 \pm 0.07^{\mathrm{b}}$ \\
Cast biomass $\left(\mathrm{g} / \mathrm{m}^{2}\right)$ & $15483.63 \pm 2446.20^{\mathrm{c}}$ & $13270.83 \pm 741.53^{\mathrm{b}}$ & $8828.13 \pm 1205.25^{\mathrm{a}}$ \\
\hline
\end{tabular}

Means with the same superscript in a column are not significantly different $(\mathrm{p}<0.05)$ 
Table 2: Descriptive statistics of physicochemical parameters in the parent soil

\begin{tabular}{llll}
\hline & Gmelina $(\mathrm{n}=7)$ & Cashew $(\mathrm{n}=5)$ & Banana $(\mathrm{n}=7)$ \\
\cline { 2 - 4 } Parameters & Mean \pm SD & Mean \pm SD & Mean \pm SD \\
\hline$\%$ OC & $2.15 \pm 1.02^{\mathrm{c}}$ & $1.32 \pm 0.80^{\mathrm{a}}$ & $1.85 \pm 0.19^{\mathrm{b}}$ \\
$\%$ OM & $3.94 \pm 1.27^{\mathrm{b}}$ & $2.30 \pm 1.31^{\mathrm{a}}$ & $3.22 \pm 0.35^{\mathrm{b}}$ \\
\% Nitrates & $0.61 \pm 0.15^{\mathrm{b}}$ & $0.53 \pm 0.60^{\mathrm{a}}$ & $0.59 \pm 0.11^{\mathrm{ab}}$ \\
\% Sulphates & $22.79 \pm 2.53^{\mathrm{a}}$ & $19.95 \pm 0.16^{\mathrm{a}}$ & $23.53 \pm 6.06^{\mathrm{a}}$ \\
pH & $7.06 \pm 0.22^{\mathrm{a}}$ & $7.32 \pm 0.35^{\mathrm{b}}$ & $7.39 \pm 0.28^{\mathrm{bc}}$ \\
\% Total Nitrogen & $0.44 \pm 0.14^{\mathrm{b}}$ & $0.34 \pm 0.56^{\mathrm{a}, \mathrm{b}}$ & $0.27 \pm 0.10^{\mathrm{a}}$ \\
\hline
\end{tabular}

Means with the same superscript in a column are not significantly different $(\mathrm{p}<0.05)$

Table 2: Descriptive Statistics of mineral elements in earthworm casts and parent soil under the three plantations

\begin{tabular}{llrrr}
\hline Sample & Minerals & $\begin{array}{r}\text { Gmelina } \\
\text { Mean } \pm \text { SD } \\
(\mathrm{mg} \mathrm{kg}-1)\end{array}$ & $\begin{array}{r}\text { Cashew } \\
\text { Mean } \pm \text { SD } \\
(\mathrm{mg} \mathrm{kg}-1)\end{array}$ & $\begin{array}{r}\text { Banana } \\
\text { Mean } \pm \text { SD } \\
(\mathrm{mg} \mathrm{kg}-1)\end{array}$ \\
\hline Earthworm cast & $\mathrm{Cu}$ & $0.07 \pm 0.03^{\mathrm{a}}(\mathrm{n}=7)$ & $0.01 \pm 0.00^{\mathrm{b}}(\mathrm{n}=5)$ & $0.09 \pm 0.08^{\mathrm{a}}(\mathrm{n}=7)$ \\
& $\mathrm{Mg}$ & $0.15 \pm 0.01^{\mathrm{a}}(\mathrm{n}=7)$ & $0.15 \pm 0.00^{\mathrm{a}}(\mathrm{n}=5)$ & $0.16 \pm 0.00^{\mathrm{a}}(\mathrm{n}=7)$ \\
& $\mathrm{Mn}$ & $0.47 \pm 0.03^{\mathrm{b}}(\mathrm{n}=7)$ & $0.44 \pm 0.05^{\mathrm{ab}}(\mathrm{n}=5)$ & $0.31 \pm 0.10^{\mathrm{a}}(\mathrm{n}=7)$ \\
& $\mathrm{Fe}$ & $7.23 \pm 0.18^{\mathrm{c}}(\mathrm{n}=7)$ & $6.03 \pm 0.20^{\mathrm{b}}(\mathrm{n}=5)$ & $5.47 \pm 0.40^{\mathrm{a}}(\mathrm{n}=7)$ \\
& $\mathrm{Na}$ & $1.66 \pm 0.65^{\mathrm{a}}(\mathrm{n}=7)$ & $1.70 \pm 0.12^{\mathrm{a}}(\mathrm{n}=5)$ & $1.52 \pm 0.61^{\mathrm{a}}(\mathrm{n}=7)$ \\
Parent soil & $\mathrm{K}$ & $1.23 \pm 0.12^{\mathrm{b}}(\mathrm{n}=7)$ & $1.09 \pm 0.06^{\mathrm{a}}(\mathrm{n}=5)$ & $1.42 \pm 0.56^{\mathrm{b}}(\mathrm{n}=7)$ \\
& $\mathrm{Cu}$ & $0.09 \pm 0.07^{\mathrm{b}}(\mathrm{n}=6)$ & $0.01 \pm 0.00^{\mathrm{a}}(\mathrm{n}=4)$ & $0.03 \pm 0.01^{\mathrm{a}}(\mathrm{n}=7)$ \\
& $\mathrm{Mg}$ & $0.15 \pm 0.01^{\mathrm{a}}(\mathrm{n}=7)$ & $0.13 \pm 0.00^{\mathrm{a}}(\mathrm{n}=5)$ & $0.15 \pm 0.01^{\mathrm{a}}(\mathrm{n}=7)$ \\
& $\mathrm{Mn}$ & $0.29 \pm 0.07^{\mathrm{a}}(\mathrm{n}=7)$ & $0.26 \pm 0.08^{\mathrm{a}}(\mathrm{n}=5)$ & $0.22 \pm 0.05^{\mathrm{a}}(\mathrm{n}=7)$ \\
& $\mathrm{Fe}$ & $6.09 \pm 0.29^{\mathrm{b}}(\mathrm{n}=7)$ & $4.92 \pm 0.79^{\mathrm{a}}(\mathrm{n}=5)$ & $4.74 \pm 0.56^{\mathrm{a}}(\mathrm{n}=6)$ \\
& $\mathrm{Na}$ & $1.41 \pm 0.08^{\mathrm{b}}(\mathrm{n}=7)$ & $1.08 \pm 0.12^{\mathrm{a}}(\mathrm{n}=5)$ & $1.46 \pm 0.23^{\mathrm{b}}(\mathrm{n}=6)$ \\
& $\mathrm{K}$ & $0.73 \pm 0.08^{\mathrm{b}}(\mathrm{n}=7)$ & $0.59 \pm 0.03^{\mathrm{a}}(\mathrm{n}=5)$ & $0.95 \pm 0.24^{\mathrm{c}}(\mathrm{n}=7)$ \\
\hline
\end{tabular}

Means with the same superscript in a column are not significantly different $(\mathrm{p}>0.05)$

Table 3: Independent Samples T-Test of mineral and nutrient contents of the soil and cast under the different plantations

\begin{tabular}{lcrrrrr}
\hline Parameters & \multicolumn{3}{c}{ Gmelina } & \multicolumn{2}{c}{ Cashew } & Banana \\
\cline { 2 - 6 } & $\mathrm{t}$ & $\begin{array}{r}\text { Sig. } \\
\text { (2-tailed) }\end{array}$ & $\mathrm{t}$ & $\begin{array}{r}\text { Sig. } \\
\text { (2-tailed) }\end{array}$ & $\mathrm{t}$ & $\begin{array}{r}\text { Sig. } \\
\text { (2-tailed) }\end{array}$ \\
\hline \% Organic carbon & -5.761 & 0.001 & -4.487 & 0.002 & -4.979 & 0.001 \\
\% Organic matter & -6.963 & 0.001 & -4.618 & 0.002 & -4.924 & 0.001 \\
pH & -1.622 & 0.131 & -.620 & 0.553 & -2.027 & 0.065 \\
\% Nitrate & -.609 & 0.554 & .142 & 0.891 & 1.731 & 0.109 \\
\% Sulphate & -2.289 & 0.041 & 190.582 & 0.001 & 6.742 & 0.001 \\
\% Total Nitrogen & 3.137 & 0.009 & 4.919 & 0.001 & 1.063 & 0.309 \\
Cu (mg kg-1) & .926 & 0.374 & -2.020 & 0.083 & -2.073 & 0.060 \\
Mg (mg kg-1) & -1.809 & 0.096 & -7.299 & 0.001 & -1.919 & 0.079 \\
Mn (mg kg-1) & -6.237 & 0.001 & -4.285 & 0.003 & -1.818 & 0.094 \\
Fe (mg kg-1) & -8.237 & 0.001 & -3.029 & 0.016 & -2.737 & 0.019 \\
Na (mg kg-1) & -1.012 & 0.331 & -8.000 & 0.001 & -.232 & 0.821 \\
K (mg kg-1) & -9.153 & 0.001 & -16.437 & 0.001 & -2.013 & 0.067 \\
\hline
\end{tabular}

